\title{
Quantification of Greenhouse Gas Emissions from Windrow Composting of Garden Waste
}

Andersen, Jacob Kragh; Boldrin, Alessio; Samuelsson, Jerker; Christensen, Thomas Højlund; Scheutz, Charlotte

Published in:

Journal of Environmental Quality

Link to article, DOI:

10.2134/jeq2009.0329

Publication date:

2010

Document Version

Peer reviewed version

Link back to DTU Orbit

Citation (APA):

Andersen, J. K., Boldrin, A., Samuelsson, J., Christensen, T. H., \& Scheutz, C. (2010). Quantification of Greenhouse Gas Emissions from Windrow Composting of Garden Waste. Journal of Environmental Quality, 39(2), 713-724. https://doi.org/10.2134/jeq2009.0329

\section{General rights}

Copyright and moral rights for the publications made accessible in the public portal are retained by the authors and/or other copyright owners and it is a condition of accessing publications that users recognise and abide by the legal requirements associated with these rights.

- Users may download and print one copy of any publication from the public portal for the purpose of private study or research.

- You may not further distribute the material or use it for any profit-making activity or commercial gain

- You may freely distribute the URL identifying the publication in the public portal 
Accepted for publication in Journal of Environmental Quality

\title{
Quantification of Greenhouse Gas Emissions from Windrow Composting of Garden Waste
}

\author{
Charlotte Scheutz ${ }^{1}$ \\ ${ }^{1}$ Department of Environmental Engineering \\ Technical University of Denmark \\ Kgs. Lyngby, Denmark \\ ${ }^{2}$ Department of Radio and Space Science \\ Chalmers University of Technology \\ SE-41296 Gothenburg, Sweden
}

Jacob K. Andersen ${ }^{1}$, Alessio Boldrin ${ }^{1}$, Jerker Samuelsson ${ }^{2}$, Thomas H. Christensen ${ }^{1}$,

"NOTE: this is the author's version of a work that was accepted for publication in Journal of Environmental Quality. Changes resulting from the publishing process, such as peer review, editing, corrections, structural formatting, and other quality control mechanisms may not be reflected in this document. Minor changes may have been made to this manuscript since it was accepted for publication.

A definitive version is published in Journal of Environmental Quality, vol 39, pp 713-724, doi: 10.2134/jeq2009.0329" 


\begin{abstract}
Microbial degradation of organic wastes entails the production of various gases such as carbon dioxide $\left(\mathrm{CO}_{2}\right)$, methane $\left(\mathrm{CH}_{4}\right)$, nitrous oxide $\left(\mathrm{N}_{2} \mathrm{O}\right)$, and carbon monoxide $(\mathrm{CO})$. Some of these gases are classified as greenhouse gases (GHGs), thus contributing to climate changes. A study was performed to evaluate three methods for quantifying GHG emissions from central composting of garden waste. Two small-scale methods were used at a windrow composting facility: a static flux chamber method and a funnel method. Mass balance calculations based on measurements of the carbon (C) content in the in- and out-going material showed that 91-94\% of the $C$ could not be accounted for using the small-scale methods, thereby indicating that these methods significantly underestimate GHG emissions. A dynamic plume method (total emission method) employing Fourier Transform Infra Red (FTIR) absorption spectroscopy was found to give a more accurate estimate of the GHG emissions, with $\mathrm{CO}_{2}$ emissions measured to be $127 \pm 15 \%$ of the degraded C. Additionally, with this method, $2.7 \pm 0.6 \%$ and $0.34 \pm 0.16 \%$ of the degraded $\mathrm{C}$ was determined to be emitted as $\mathrm{CH}_{4}$ and $\mathrm{CO}$. In this study, the dynamic plume method was a more effective tool for accounting for $\mathrm{C}$ losses and, therefore, we believe that the method is suitable for measuring GHG emissions from composting facilities. The total emissions were found to be $2.4 \pm 0.5 \mathrm{~kg} \mathrm{CH}_{4}-\mathrm{C} \mathrm{Mg}^{-1}$ wet waste (ww) and $0.06 \pm 0.03 \mathrm{~kg} \mathrm{~N}_{2} \mathrm{O}-\mathrm{N} \mathrm{Mg}^{-1} \mathrm{ww}$ from a facility treating $15540 \mathrm{Mg}$ of garden waste $\mathrm{yr}^{-1}$, or $111 \pm 30 \mathrm{~kg} \mathrm{CO}_{2}$-equivalents $\mathrm{Mg}^{-1} \mathrm{ww}$.
\end{abstract}

Abbreviations: FTIR, Fourier Transform Infra Red; GHG, Greenhouse Gas; GWP, Global Warming Potential; VFG, Vegetable, Fruit, and Garden; ww, wet waste. 


\section{Introduction}

Composting has become a common treatment option for garden waste in the European Union (EU). Out of approximately 2000 large commercial composting plants in the EU, $40 \%$ only treat garden waste (Barth, 2008). Garden waste composting in open windrows is state-of-the-art in all the EU countries and is nearly the only composting technology in Finland, Denmark, France, Ireland, and the UK (Barth, 2008).

Official statistics on garden waste generation quantities in the EU are scarce. This is partly because some countries do not report generation of garden waste and in some countries garden waste and household food waste is collected as a mixture termed "biowaste" or VFG (Vegetable, Fruit, and Garden) waste. However, rough estimates indicate that the quantity of garden waste composted annually has increased substantially over the past decade (ECN, 2008), suggesting an increasing trend that is likely to continue into the foreseeable future. Unofficial data from EU countries indicates that garden waste collection and composting between 2002 and 2008 has increased by approximately 100\% (4 million Mg in 2002; 7 million Mg in 2005; and 8 million Mg in 2008 (ECN, 2008)).

Detailed, quantitative studies on garden waste composting are few and, as a result, the benefits and disadvantages of composting have not been well quantified. Qualitatively, the primary benefits of composting are that mature compost can be used as a natural fertilizer in agriculture or as a conditioner to enhance structure of agricultural soils, thereby reducing reliance on industrial mineral fertilisers and/or peat. The main potential disadvantage is generation and emission of gaseous compounds such as methane $\left(\mathrm{CH}_{4}\right)$, nitrous oxide $\left(\mathrm{N}_{2} \mathrm{O}\right)$, and carbon monoxide (CO). The carbon dioxide $\left(\mathrm{CO}_{2}\right)$ emitted from composting activities originates from degradation of plant material and is usually accounted as neutral with respect to global warming (i.e. the global warming potential (GWP) of $\mathrm{CO}_{2}$ is zero (Christensen et al., 2009)). In contrast, $\mathrm{CH}_{4}$ and $\mathrm{N}_{2} \mathrm{O}$ are strong greenhouse gases (GHGs) and are recognized as contributing to the greenhouse effect. The GWP is 25 for $\mathrm{CH}_{4}$ and 298 for $\mathrm{N}_{2} \mathrm{O}$, indicating that they are 25 and 298 times more potent GHGs than $\mathrm{CO}_{2}$ over a 100 years time horizon (Solomon et al., 2007) (GWP 100 is used throughout this paper). Emission of gases is especially important from simple and common composting systems like windrows, where gases are neither controlled nor treated. Quantification of GHG emissions from composting facilities is important toward the development of technologies for mitigating emissions and improving accuracy of parameters for quantitative compost emission models. Increased availability of quantitative data on GHG emissions from composting facilities should improve comparability, consistency, and accuracy of emission data reported across various national and international databases.

The overall objective of the study was to obtain an accurate measure of the distribution of $\mathrm{CO}_{2}, \mathrm{CH}_{4}, \mathrm{~N}_{2} \mathrm{O}$, and $\mathrm{CO}$ in the pore space and emitted from a full-scale garden waste compost system. The few previous studies that have been conducted on this topic involved different gas emission estimation approaches tested at smaller scales. Beck-Friis et al. (2001) and He et al. (2001) (the latter measured only $\mathrm{N}_{2} \mathrm{O}$ ) utilized bench-scale experiments, while Beck-Friis et al. (2000) and Hellmann et al. (1997) completed pilot-scale experiments. Hellebrand (1998) combined transport modelling with pilot-scale experiments. Collectively, these studies showed that $\mathrm{CH}_{4}$ is produced during composting of organic waste even under well aerated conditions, suggesting that emission of $\mathrm{CH}_{4}$ cannot be avoided in garden waste compost systems. The 
largest emissions of $\mathrm{CH}_{4}$ occurred under thermophilic conditions. $\mathrm{N}_{2} \mathrm{O}$ was also detected in the aforementioned studies, but primarily under mesophilic conditions.

We for the first time quantified the emissions of gases at a full-scale windrow composting facility (Århus, Denmark) by three methods: static flux chamber method, funnel method (small-scale methods), and a dynamic plume method covering the whole site (total emission method). Additionally, a simple transport model, using pore space concentrations as input parameters, described by Hellebrand (1998), was tested for the full-scale composting system. The three methods and the transport model were tested at the same facility to allow a direct comparison of performance results. Herein we describe the distribution of GHGs inside the compost pore space and the quantification of emissions of these GHGs.

\section{Materials and Methods}

Measurements were collected at the full-scale windrow composting facility in Århus, Denmark over the course of multiple sampling events completed between June 2006 and April 2008. The Århus facility primarily receives garden waste from the commercial gardening industry, as well as residential gardens. The garden waste is sorted, shredded and placed in compost windrows working in an eastward direction such that the oldest windrow is located at the eastern terminus of the facility, and the youngest windrow is located at the western end of the facility (see overview picture in Fig. 1, A). The age of each windrow is determined from its date of construction. At any time during a given year, the facility has 8-12 windrows that are approximately $115 \mathrm{~m}$ long, $9 \mathrm{~m}$ wide, and $4 \mathrm{~m}$ high. The composting time is $10-14$ months depending, in part, on the frequency of turning, which is typically completed every second month via a front-end loader.

\subsection{Compost sampling and analysis of carbon and nitrogen}

Quantities of ingoing and outgoing waste at the composting facility were routinely recorded by the facility staff (Affaldscenter Århus, 2007). In 2007, the facility treated $15540 \mathrm{Mg}$ of garden waste and produced $10530 \mathrm{Mg}$ of mature compost. Solid samples were collected eight times throughout the year (twice per season) from the ingoing material to determine the carbon (C) and nitrogen ( $\mathrm{N}$ ) content. The sampling was performed based on Theory of Sampling

(Gy, 1998) and included sampling of up to $20,000 \mathrm{Mg}$ garden waste and subsequent shredding and size reduction to $5 \mathrm{~g}$ laboratory samples. The sampling method was validated using an elaborate sampling scheme (Boldrin et al. 2009b) to ensure that none of the splitting and size reduction steps significantly compromised the representativeness of the final sample. The outgoing material (compost) was much more homogeneous and was grab sampled five times during the year using a large number of increments (more than 30) to reduce uncertainty. The procedure is described by Andersen et al. (2009). 

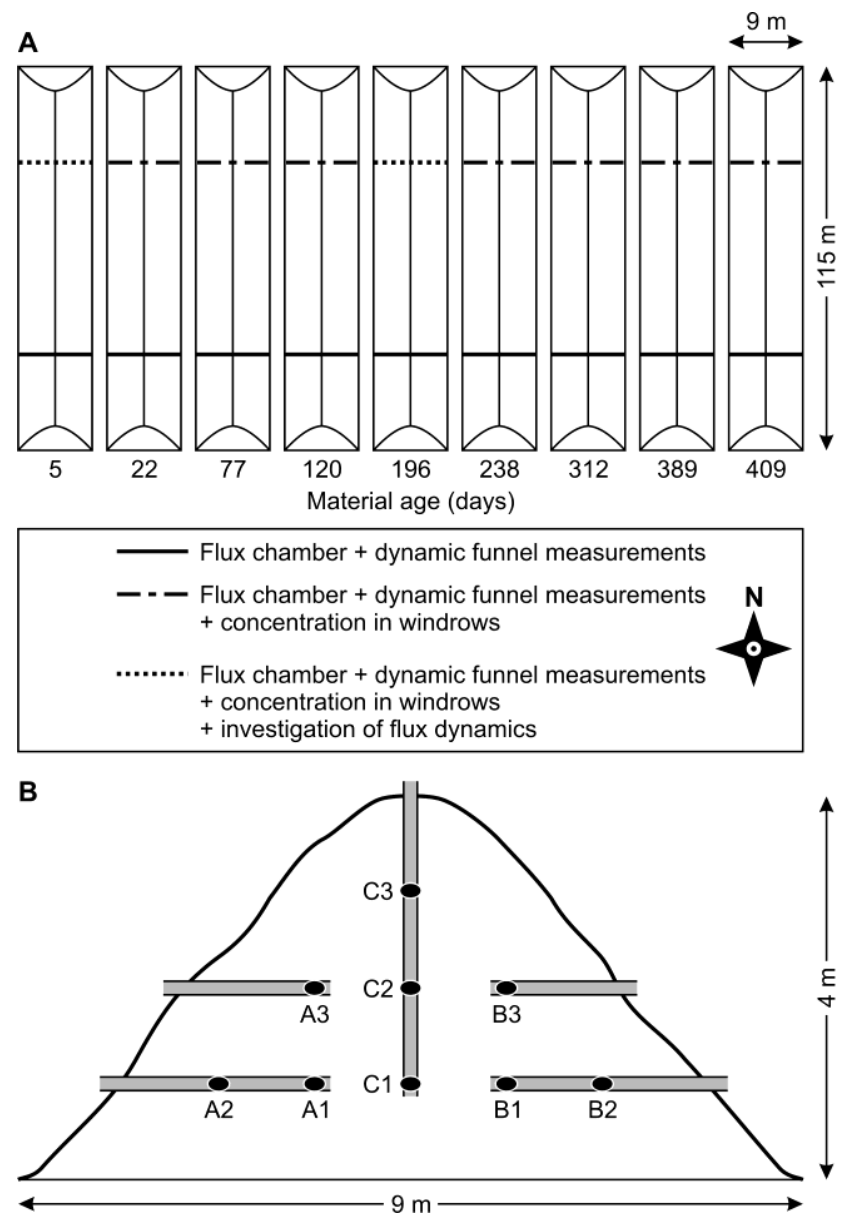

Fig. 1. A: Outline of the composting facility with indications of the monitoring points. The numbers are an example of the windrow age at a given time during composting. B: Gas monitoring points in a windrow crosssection. The gray lines represent gas probes and the black dots represent sample locations.

Samples (two replicates of each sample) were collected and analyzed for $\mathrm{C}$ and $\mathrm{N}$ in the months of June, September, and November 2006 and January, March, April, May, and August 2007. In addition to $C$ and $N$, the sample analyses included total solids (TS) and volatile solids (VS), and analyses of a range of other compounds performed at a certified commercial laboratory (ALS Scandinavia AB, Luleå, Sweden). The TS content was measured by drying the samples at $105^{\circ} \mathrm{C}$ for about 24 hours. The VS content was estimated based on mass loss after heating at $550^{\circ} \mathrm{C}$ for 1 hour. Samples for total organic carbon (TOC) analysis were prepared by drying the samples at $105^{\circ} \mathrm{C}$ for 24 hours, followed by treatment with sulphuric acid $\left(\mathrm{H}_{2} \mathrm{SO}_{4}\right)$ to eliminate any inorganic $\mathrm{C}$, with subsequent analysis on a carbon analyser. $\mathrm{N}$ was determined using the Kjeldahl-N method as described in Higson (2003).

\subsection{Sampling of compost pore space}

Concentrations of $\mathrm{CO}_{2}, \mathrm{CH}_{4}, \mathrm{~N}_{2} \mathrm{O}, \mathrm{CO}$, and $\mathrm{O}_{2}$ in the compost pore space were measured in order to map spatial and temporal variations of these gases during composting. Measurements were performed in March 2007 (eight cross-sectional measurements) and in April 2008 (six cross-sectional measurements). Gas probes with lengths of $2.5 \mathrm{~m}$ and $3.5 \mathrm{~m}$ were 
driven into the windrows in the nine monitoring points in each cross-section as shown in Fig. 1 (B). To eliminate gaseous dead space in the probes and the connection tubes prior to sample collection, each probe sampling system was flushed several times by withdrawing approximately $2 \mathrm{~L}$ of compost gas, over a period of two minutes, with a manual pump. This was done at each of the nine points in the cross-sections. All data points are mean values from duplicate samples.

\subsection{Temperature measurements}

Temperature measurements were collected by the facility staff weekly during composting. Measurements were collected approximately $1 \mathrm{~m}$ below the top of the compost windrows with a thermometer attached to a rod. Seven measurements were collected at each windrow (approximately $15 \mathrm{~m}$ between each measurement) and a mean temperature for each windrow was recorded every week.

\subsection{Measurements of GHG emissions}

Gaseous emissions of $\mathrm{CO}_{2}, \mathrm{CH}_{4}, \mathrm{~N}_{2} \mathrm{O}$, and $\mathrm{CO}$ were measured using two different smallscale methods and a total-emission measurement method. In addition, a simple transport model (Hellebrand, 1998) was used for comparison with the measured emissions. The three methods for quantification of GHGs are briefly described below together with the transport model.

The small-scale measurements were collected from two monitoring points on the surface of each windrow (see Fig. 1, A). Measurement stations were located on top of each windrow because it was assumed that this location is where the major fraction of gas emission occurs. This assumption, which was expected based on the chimney effect that commonly prevails in windrow systems due to convection (Hellmann et al., 1997), was validated at the facility through the results of flux measurements collected across a windrow (see section: "Gas emission pattern across compost windrows" in the Results Section).

The first small-scale method used was a static flux chamber method. This method was described by Beck-Friis et al. (2000), Börjesson and Svensson (1997), Livingston and Hutchinson (1995), and Scheutz et al. $(2003,2007)$ among others. Due to the flux $\left(F_{\text {Flux chamber }}\right)$ of gases through the top of the compost material, the concentration of gases $\left(C_{\text {gas }}\right)$ increased linearly inside the flux chamber over time, and the change in concentration over time $\left(\mathrm{dC}_{\text {gas }} / \mathrm{dt}\right)$ could be calculated. Based on the change in gas concentration and the dimensions of the chamber $\left(\mathrm{V}_{\text {chamber }} / \mathrm{A}_{\text {chamber }}\right), \mathrm{F}_{\text {Flux chamber }}$ was calculated as follows:

$F_{\text {Fluxchamber }}=\frac{d C_{\text {gas }}}{d t} \cdot \frac{V_{\text {chamber }}}{A_{\text {chamber }}}$

Two different chambers were used to measure gas fluxes (both with an air-tight roof and an open bottom); a round aluminium chamber with a diameter of $31 \mathrm{~cm}\left(\mathrm{~V}_{\text {chamber }}=0.015 \mathrm{~m}^{3}\right)$ and a squared, wooden chamber with an area of $1 \mathrm{~m}^{2}\left(\mathrm{~V}_{\text {chamber }}=0.40 \mathrm{~m}^{3}\right)$. The smaller chamber was used to investigate the chimney effect locally at the windrow apex. As it covered a wider, larger surface area of the windrow, the larger chamber was used to collect a broader measure of gas flux from the windrow. The large chamber was used during sampling events in November 2007 and April 2008 (19 measurements in total; the flux from material with similar age has been averaged giving 12 measurement points in Fig. 8). Each of the flux measurements were 
performed over a period of around 5-8 minutes, as this interval gave linear responses for all gases measured.

The other small-scale method is termed the funnel method. This method was developed by the consulting firm Rambøll and used to estimate ammonia $\left(\mathrm{NH}_{3}\right)$ emissions from compost windrows. The instrument is made of aluminium and resembles an upside-down funnel with a vent pipe attached on top from where the gases escape through. The vent pipe is approximately $1.8 \mathrm{~m}$ high and has a diameter of $8 \mathrm{~cm}$ with a narrower top to control turbulence. The funnel covered $1 \mathrm{~m}^{2}$ at the windrow top (as the large flux chamber). The flux $\left(F_{\text {funnel }}\right)$ was calculated according to Equation 2 using steady-state measurements of the gas concentration $\left(C_{\text {gas }}\right)$ and the air flow velocity ( $v_{\text {air }}$; values ranged from 0.09 to $0.26 \mathrm{~m} / \mathrm{s}$ ) in the vent pipe, as well as the cross sectional areas of the vent pipe $\left(A_{\text {vent pipe }}\right)$ and funnel $\left(A_{\text {funnel }}\right)$.

$F_{\text {funnel }}=\frac{C_{\text {gas }} \cdot v_{\text {air }} \cdot A_{\text {vent pipe }}}{A_{\text {funnel }}}$

The dynamic funnel was used during sampling events in May 2007, November 2007, and April 2008 (19 measurements in total). Each of the dynamic funnel measurements were averaged over 15-20 minutes.

A dynamic plume method was used to determine the total emissions from the facility. This method combines a controlled tracer gas release with concentration measurements in the downwind plume (of the composting facility). A mobile Fourier Transform Infra Red (FTIR) system was used to measure the plume concentrations. The FTIR instrument was operated with a time resolution of 40 seconds and $1 \mathrm{~cm}^{-1}$ spectral resolution and the measuring inlet was in approximately $2 \mathrm{~m}$ height. For quantification of $\mathrm{CO}_{2}, \mathrm{CH}_{4}$, and $\mathrm{CO}, \mathrm{N}_{2} \mathrm{O}$ was used as tracer, whereas for $\mathrm{N}_{2} \mathrm{O}$ (and $\mathrm{CO}_{2}$ and $\mathrm{CH}_{4}$ ) quantification $\mathrm{CO}$ was used. $\mathrm{N}_{2} \mathrm{O}$ tracer was released in four points representing each corner of the composting area. The $\mathrm{CO}$ was released from one central point of the area. Both tracers were released on top of the compost material at a height of approximately $5 \mathrm{~m}$. The release of the two tracers occurred at different periods in order to be able to separate the natural concentrations of $\mathrm{N}_{2} \mathrm{O}$ and $\mathrm{CO}$ from the tracer concentrations. The tracer release rate was $9.6 \mathrm{~kg} \mathrm{~N}_{2} \mathrm{O} \mathrm{h}^{-1}$ and $2.1 \mathrm{~kg} \mathrm{CO} \mathrm{h}^{-1}$ respectively. The natural $\mathrm{N}_{2} \mathrm{O}$ emissions from the degradation of organic material (natural emissions) were much lower than the total $\mathrm{N}_{2} \mathrm{O}$ emission when the $\mathrm{N}_{2} \mathrm{O}$ tracer was released. The plume concentrations of $\mathrm{N}_{2} \mathrm{O}$ were between 80 and 150 times higher when the $\mathrm{N}_{2} \mathrm{O}$ tracer was released (770 ppbv in October 2007) compared to the natural plume concentration ( $<5$ ppbv in October 2007). When released to the atmosphere the tracer is dispersed in the same way as the emitted gases, given good mixing conditions, and the cross plume integrated concentration ratio of the gases to tracer can be used to calculate the gas emission rate $\left(E_{\text {gas }}\right)$ as follows:

$$
E_{\text {gas }}=Q_{\text {tracer }} \cdot \frac{\int_{\text {Plumeend } 1}^{\text {Plumeend } 2} C_{\text {gas }} d x}{\int_{\text {Plumeend } 1}^{\text {Plumer } 2} C_{\text {tracer }} d x} \cdot \frac{M W_{\text {gas }}}{M W_{\text {tracer }}}
$$

where $Q_{\text {tracer }}$ is the release rate of the tracer gas, $C_{\text {gas }}$ and $C_{\text {tracer }}$ denote the cross plume integrated concentrations above background (background measurements were performed prior to emission measurements), MW denotes molecular weight, and $\mathrm{x}$ corresponds to distance 
cross the plume (between 100 and $200 \mathrm{~m}$ for all cross plumes). Repeated plume integrations during a one to three hour period typically result in a robust estimate of average emission and variability for that time frame (including source variability and method uncertainties).

The method was developed for measuring $\mathrm{CH}_{4}$ from landfills, as described by Börjesson et al. (2009) and Galle et al. (2001), and has also been applied successfully for measurement of gas emissions at petrochemical plants (ethylene, propylene and ammonia (Mellqvist, 1999)). To our knowledge, this is the first time that the dynamic plume method (and any other total emission method for that matter) has been applied on a full-scale composting facility. The dynamic plume method was used during sampling events in October 2007 (8 plume integrations with $\mathrm{N}_{2} \mathrm{O}$ as tracer and 3 plume integrations with $\mathrm{CO}$ as tracer) and April 2008 (11 plume integrations with $\mathrm{N}_{2} \mathrm{O}$ as tracer and 7 plume integrations with $\mathrm{CO}$ as tracer). This means that $\mathrm{CO}_{2}$ and $\mathrm{CH}_{4}$ was estimated from 29 plume integrations, $\mathrm{N}_{2} \mathrm{O}$ from 10 plume integrations and $\mathrm{CO}$ from 19 plume integrations. Each of the sampling events was performed during 2 days with approximately 3 hours of sampling per day. During both campaigns, the weather conditions were monitored carefully. On all measuring days the weather was clear skies (no rain) and average temperatures were $8-11^{\circ} \mathrm{C}$ (in October 2007) and $4-8^{\circ} \mathrm{C}$ (April 2008). The wind speed was $2-5 \mathrm{~m} / \mathrm{s}$ in both campaigns coming from the NW $\left(340^{\circ}\right)$ to WSW $\left(252^{\circ}\right)$, which means that all measurements were performed east (downwind) of the composting plant. The barometric pressure was between 1000-1012 mbar during all measurements.

Apart from the three measuring methods, a gas emission prediction was made, based on a simple transport model described by Hellebrand (1998). The model is based on concentration measurements in the compost pore space and the loss of $\mathrm{C}$ during composting. The measurements by Hellebrand (1998) were performed on trapezoidal heaps of garden waste with dimensions of $11 \mathrm{~m}$ in length, $7 \mathrm{~m}$ in width and $3 \mathrm{~m}$ in height. The mean concentration of $\mathrm{C}$ containing gases $\left(\mathrm{CO}_{2}, \mathrm{CH}_{4}\right.$, and $\left.\mathrm{CO}\right)\left(\mathrm{C}_{\text {carbon total }}\right)$ and the concentration of the gases $\left(\mathrm{C}_{\text {gas }}\right)$ in the compost pore space were needed from the experimental setup. The emission rate of the gas under study $\left(Q_{\text {gas }}\right)$ can be found when the emission rate of $C\left(Q_{\text {carbon }}\right)$ is known (assumed to be the loss of $C$ during composting). $\mathrm{D}_{\text {gas }}$ and $\mathrm{D}_{\mathrm{CO} 2}$ are the diffusion coefficients of the gas and $\mathrm{CO}_{2}$ respectively. According to Richter et al. (2006), $\mathrm{D}_{\mathrm{CO}} / \mathrm{D}_{\mathrm{CO} 2}=1.25, \mathrm{D}_{\mathrm{N} 2 \mathrm{O}} / \mathrm{D}_{\mathrm{CO} 2}=1$ and $\mathrm{D}_{\mathrm{CH} 4} / \mathrm{D}_{\mathrm{CO} 2}=$ 1.66. The relationship is:

$Q_{\text {gas }}=\frac{D_{\text {gas }}}{D_{\mathrm{CO}_{2}}} \cdot \frac{Q_{\text {carbon }} \cdot C_{\text {gas }}}{C_{\text {carbontotal }}}$

In the study by Hellebrand (1998), the transport model was used on a system with other dimensions compared to this study and the conditions are therefore slightly different.

\subsection{Analysis of the gases}

The gas samples taken from the compost pore space were analysed in the field for $\mathrm{CO}_{2}$ (calibrated for concentrations $<1 \%$ ), $\mathrm{CH}_{4}$ (calibrated for concentrations $<2 \%$ ), $\mathrm{N}_{2} \mathrm{O}$, and $\mathrm{CO}$ using a photo acoustic gas monitor (INNOVA 1312; Lumasense Technologies A/S, 2750 Ballerup, Denmark). The advantages of this instrument is that it measures on location in real time, has high accuracy over a broad concentration range and only one calibration is necessary per year (calibration is done by the producer). The inlet is equipped with a water filter (Genie membrane 
separator, A+ Corporation, USA) that ensures that no moisture is transferred to the measuring chamber. The detection limits were 1.5, 0.4, 0.2, and 0.03 ppmv for $\mathrm{CO}_{2}, \mathrm{CH}_{4}, \mathrm{CO}$, and $\mathrm{N}_{2} \mathrm{O}$.

Samples were also collected from each sample station with a syringe and transferred to a vacuum vial ( $5 \mathrm{~mL}$ Exetainer glass vials) and subsequently analysed in the laboratory on a micro-gas chromatograph (GC) (CP2002P; Chrompack, Bergen op Zoom, The Netherlands) for $\mathrm{CO}_{2}(>1 \%), \mathrm{CH}_{4}(>2 \%), \mathrm{O}_{2}$, and $\mathrm{N}_{2}$. The instrument was calibrated before measurement for 1$100 \% \mathrm{CO}_{2}$ and $2-100 \% \mathrm{CH}_{4}$.

The flux and funnel measurement samples were analysed in the field for $\mathrm{CO}_{2}, \mathrm{CH}_{4}, \mathrm{~N}_{2} \mathrm{O}$, and $\mathrm{CO}$ by continuously sampling with a 1 minute interval using an INNOVA 1312 . The measurements of GHGs using the dynamic plume method were performed using FTIR absorption spectroscopy (Bomem MB104; Galle et al., 2001), calibrated for $\mathrm{CO}_{2}, \mathrm{CH}_{4}, \mathrm{~N}_{2} \mathrm{O}$, and CO.

In total, $2 \times 126$ gas samples from the compost pore space were analysed and 38 measurements (more than 500 gas samples) were performed with the small-scale methods. The dynamic plume method was used during two sampling events and a total of 29 plume transect measurements were performed.

\section{Results}

Mass balance for $\mathrm{C}$ and $\mathrm{N}$ based on analysis of compost material

Table 1 shows the average annual inputs and outputs of the total amount of material, TS, VS, ash, C, and N contents (based on 2007). The ash content was more or less the same in the input and output material. The TS, VS, C, and N content decreased presumably due to degradation of organic material. The mass loss to air was $28 \%$ and the loss of VS was $56 \%$, which was equivalent to the percentage of $\mathrm{C}$ degraded during composting (loss of $1379 \mathrm{Mg} \mathrm{C}$ out of $2465 \mathrm{Mg} \mathrm{C}$ ). The degradation of $\mathrm{N}$ was $8 \%$ (loss of $4.3 \mathrm{Mg} \mathrm{N}$ out of 53.9 Mg N). The mass, $\mathrm{C}$, and $\mathrm{N}$ flow analyses were described in detail by Andersen et al. (2009). The difference between the total input and output does not necessarily entirely equate to gaseous loss, as other loss mechanisms might have occurred.

Table 1. Mass of material, TS, VS, Ash, C, and N for the incoming waste and the outgoing compost. All numbers are annual averages (based on 2007).

\begin{tabular}{|l|c|c|}
\hline & Input & Output \\
\hline Material (Mg ww) & 15540 & 10540 \\
\hline TS (Mg) & 9498 & 7322 \\
\hline Total C (Mg) & 2465 & 904 \\
\hline Total N (Mg) & 53.9 & 49.6 \\
\hline Total ash (Mg) & 5372 & 5305 \\
\hline Total VS (Mg) & 4764 & 1743 \\
\hline Tww, wet waste \\
\hline
\end{tabular}

\subsection{Temperature in compost windrows over time}

An example of the weekly temperature measurement results for a single windrow over the entire composting process is presented in Fig. 2. Significant temperature increases were observed relatively rapidly, reaching $60^{\circ} \mathrm{C}$ within the first week. The temperature peaked at 
about $80^{\circ} \mathrm{C}$ after $200-270$ days. After each turning event, the temperature within the windrows decreased markedly and settled below $70^{\circ} \mathrm{C}$. At the end of composting (after more than a year) the temperature had reached $50-55^{\circ} \mathrm{C}$. This development indicates that the microbial activity and waste decomposition was greatest in the first half of the composting process. The temperature data indicate that turning temporarily reduced temperature, and possibly, bioactivity within the windrows. At the first three turning events the temperature quickly returned to the same level after a large drop, whereas at turning events 4 and 5 (Fig. 2), the temperature settled at a lower level. This could suggest that the turning events in this later period of composting facilitated a decrease in the degradation rate. In general, it is common in the early stages of composting to observe increasing temperatures followed by a stabilized temperature phase and then a decreasing temperature phase towards the end of composting. This trend has also been described by Beck-friis et al. (2000), Hellebrand (1998), and Hellmann et al. (1997). However, it is interesting in this work that temperatures were consistently above $50^{\circ} \mathrm{C}$ (thermophilic) over the entire composting period, even during the cooling/maturation phase. This result could be related to the size of the windrows.

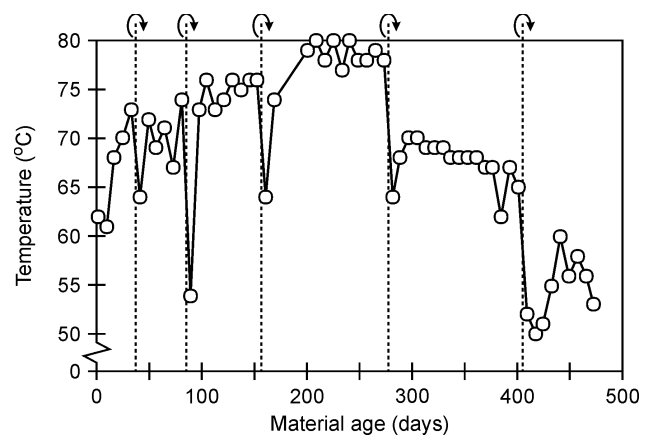

Fig. 2. Temperature development during windrow composting of garden waste. The graph shows an example from a single windrow during the entire composting period (from February 2006 to May 2007). The dotted lines and arrows represent turning events.

\subsection{Compost gas composition}

Cross-sectional gas concentration profiles in the windrows are presented in Fig. 3. The average concentrations of the gases in all of the monitoring points ( $14 \times 9$ points $=126$ points) were $8.8 \% \mathrm{O}_{2}, 17.7 \% \mathrm{CO}_{2}, 6.7 \% \mathrm{CH}_{4}, 138$ ppmv $\mathrm{N}_{2} \mathrm{O}$, and 51 ppmv $\mathrm{CO}$ respectively. $\mathrm{CO}_{2}$ and $\mathrm{CH}_{4}$ were produced primarily in the central parts of the windrows, where the lowest concentrations of $\mathrm{O}_{2}$ were found. The concentration of $\mathrm{N}_{2} \mathrm{O}$ was more evenly distributed in the profiles but with slightly higher concentrations in the central parts. The concentration profiles indicate that a chimney effect (illustrated in Fig. 4) developed in the windrows due to the convective transport of gases. The highest concentrations of $\mathrm{CO}$ were found on the western side of the windrow. One possible explanation for this result is that the predominant wind direction on the days of measurement was from east to west, and this likely caused greater pressure and pore gas dilution on the eastern side of the windrow relative to the western side, which was sheltered from the wind. This same effect was also to some extent evident for the other gases (Fig. 3) and $\mathrm{O}_{2}$ concentrations were higher on the eastern side of the windrow, presumably due to winddriven aeration. 


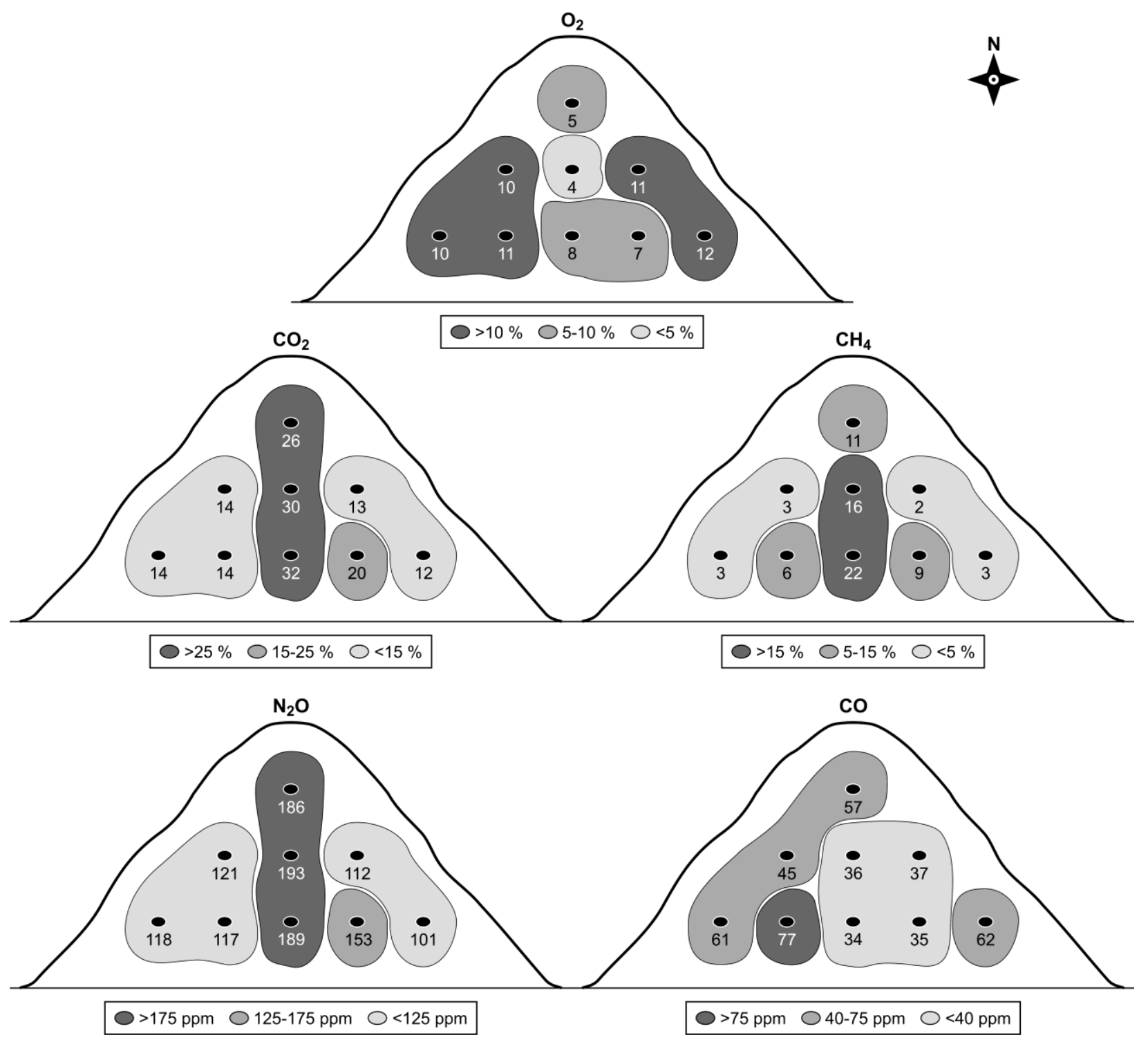

Fig. 3. Cross-sectional distribution of $\mathrm{O}_{2}, \mathrm{CO}_{2}$, and $\mathrm{CH}_{4}$ (in volume \%) and $\mathrm{N}_{2} \mathrm{O}$ and $\mathrm{CO}$ (in ppmv) in compost pore space. The numbers are average concentrations during the entire composting process and they are based on eight cross-sectional measurements in March 2007 and six cross-sectional measurements in April 2008. The average material age is $\mathbf{2 4 3}$ days. Note that the primary wind direction was from the East on the days of data collection.

The gas composition and distribution results are consistent with the range of microbial processes that are typically expected to occur in a composting system. Oxygen consumption and $\mathrm{CO}_{2}$ production provided evidence of aerobic degradation processes, while $\mathrm{CH}_{4}$ and $\mathrm{CO}_{2}$ production provided evidence of anaerobic (methanotrophic) degradation processes. Production of $\mathrm{N}_{2} \mathrm{O}$ indicated that nitrification and/or denitrification also occurred. Accumulation of CO occurs commonly in windrows when oxygen is present (e.g., Hellebrand (1998) and Hellebrand and Kalk (2001)). 


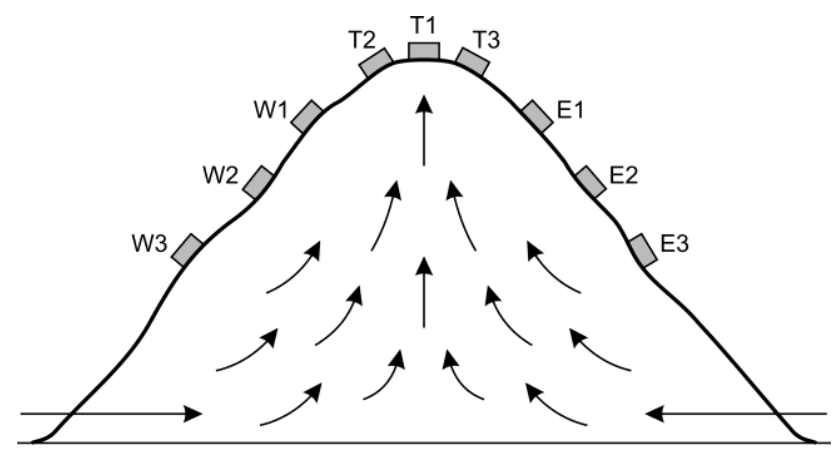

Fig. 4. Conceptual drawing of the "chimney effect". The gas is drawn in at the sides of the windrow and the gases are emitting through the top centre. The monitoring points of the small flux chambers for the measurement of flux dynamics are shown on top of the windrow. "T" denotes top, " $E$ " denotes east, and "W" denotes west.

The gas composition in the windrows varied significantly over time, although some trends were evident (Fig. 5). The $\mathrm{O}_{2}$ concentration was highest during early stages of composting (12-19\%) and decreased with time, with concentrations reduced to $4-7 \%$ in most cases by the end the monitoring period. $\mathrm{CO}_{2}, \mathrm{CH}_{4}$, and $\mathrm{N}_{2} \mathrm{O}$ concentrations in the compost pore space generally increased over this same period and maximum concentrations for these three gases were observed within 200-350 days of composting. The peak concentration of CO was observed somewhat earlier than the other gases (180-250 days).

These gas concentration data indicate that the windrows studied in this work produced significant quantities of GHGs and suggest that windrows in general may serve as a source for GHG emissions to the atmosphere. Whether the gases were emitted depends on a range of processes in the windrows including $\mathrm{CH}_{4}$ oxidation.

\subsection{Gas emission patterns across compost windrows}

The conventional model for gas emissions from compost windrows involves loss primarily occurring through the windrow top with ambient air entering at the windrow sides (Fig. 4). In this work, the chimney effect was investigated by measuring gas emissions with a small flux chamber at nine different locations across a windrow in a random place in the system (material age was 77 days). The flux measurement monitoring points covered the entire width of the windrow (see Fig. 4) and the distribution of fluxes across the windrow is presented in Fig. 6. The nine flux measurements were collected successively over a 90 minute sampling period.

The fluxes at the nine points showed the same pattern for all gases measured. The highest fluxes were observed at monitoring points T1, T3, and T2 (located near the windrow top), and nearly all other points showed insignificant gas flux. These results suggest the development of conditions that are consistent with a chimney effect. The fluxes at T1 and $\mathrm{T} 1+\mathrm{T} 2+\mathrm{T} 3$ are compared to the fluxes from all nine points in Table 2. Approximately $50 \%$ of the fluxes were captured when the flux chamber was used at point T1, while $85-100 \%$ was captured at points $\mathrm{T} 1+\mathrm{T} 2+\mathrm{T} 3$ combined. A significantly higher flux was observed at $\mathrm{T} 3(30-44 \%)$ relative to T2 (1-12\%), likely due to wind effects. On the day the fluxes were measured, the wind came in from the west, thereby creating conditions for a diluted flux at T2. The higher pressure caused by the wind on the western side could also make the fluxes emerge on the eastern side of the windrow. The investigation indicates that most (>85\%) of the gases vented through a narrow ( 1 
$m$ wide), chimney-like area in the top of the windrow. These results also confirmed that the flux chamber have to cover the top $1 \mathrm{~m}$, and therefore the small flux chamber is not suitable for effectively sample and quantify gas emissions from a compost windrow.
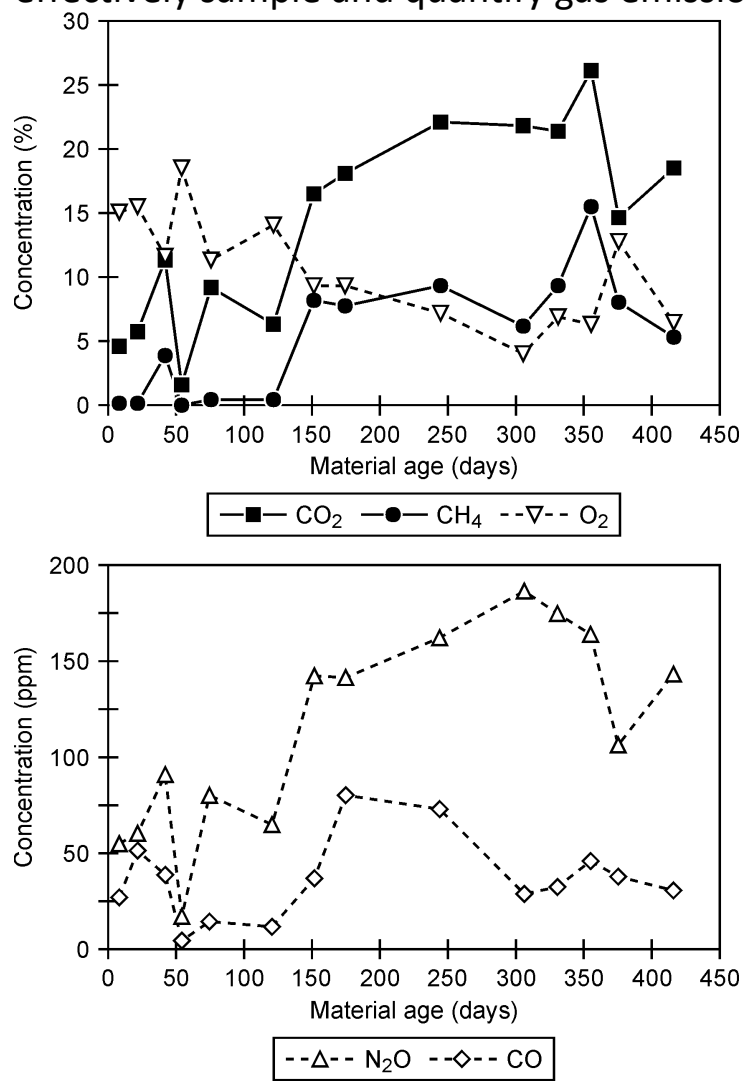

Fig. 5. Mean concentration of $\mathrm{O}_{2}, \mathrm{CO}_{2}$ and $\mathrm{CH}_{4}$ (top graph, in \%), $\mathrm{N}_{2} \mathrm{O}$ and $\mathrm{CO}$ (bottom graph, in ppmv) in compost pore space during composting of garden waste. The data originates from two field campaigns with eight measurements in March 2007 and six measurements in April 2008. Each point is a mean value of the nine points in the cross sections.

Table 2. Fluxes from the top part of the windrow compared to the total fluxes from all measurement points at the top and the sides of the windrow.

\begin{tabular}{|l|c|c|c|c|}
\hline & $\begin{array}{c}\mathbf{C O}_{\mathbf{2}} \\
\mathbf{\%}\end{array}$ & $\begin{array}{c}\mathbf{C H}_{\mathbf{4}} \\
\mathbf{\%}\end{array}$ & $\begin{array}{c}\mathbf{N}_{\mathbf{2}} \mathbf{O} \\
\mathbf{\%}\end{array}$ & $\begin{array}{c}\mathbf{C O} \\
\mathbf{\%}\end{array}$ \\
\hline $\begin{array}{l}\text { Flux at T1 } \\
\text { compared to total flux }\end{array}$ & 46 & 55 & 49 & 43 \\
\hline $\begin{array}{l}\text { Flux at T1+T2+T3 } \\
\text { compared to total flux }\end{array}$ & 89 & 100 & 91 & 85 \\
\hline \multicolumn{1}{|l}{ 1, T2, and T3 denote top position of the flux chamber covering the top of the windrow } \\
\hline
\end{tabular}




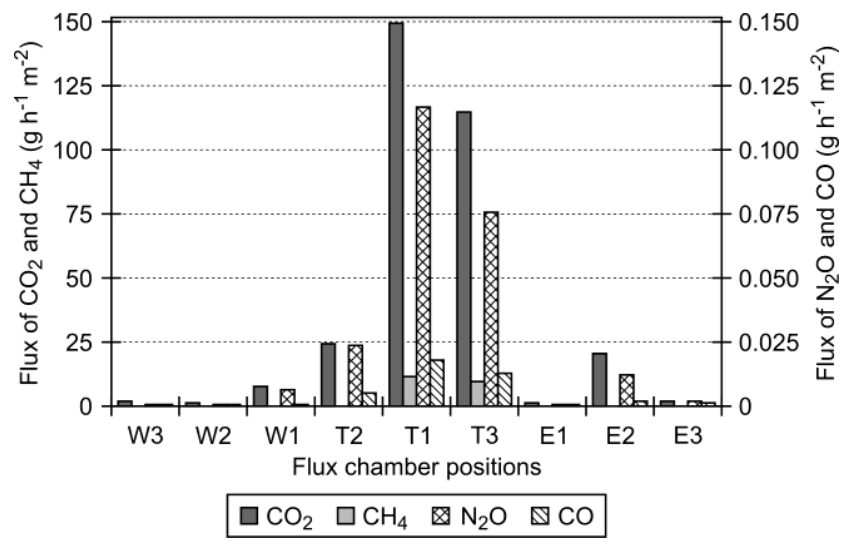

Fig. 6. Fluxes of $\mathrm{CO}_{2}, \mathrm{CH}_{4}$ (primary y-axis), $\mathrm{N}_{2} \mathrm{O}$, and $\mathrm{CO}$ (secondary y-axis) at a place in the windrow system that represents material aged 77 days.

\subsection{GHG emissions from compost windrows}

An example of the flux of gases measured using the flux chamber method is presented in Fig. 7. The $R^{2}$ values for linear regression are all $\geq 0.95$. The gas concentrations levels off in the end of the measurement period, which means that the concentration build-up is only linear for the first 5 measurements in this case. The $\mathrm{R}^{2}$ values for all 19 measurements were acceptable. They were: 0.9493 for $\mathrm{CO}_{2}, 0.9502$ for $\mathrm{N}_{2} \mathrm{O}, 0.9492$ for $\mathrm{CH}_{4}$, and 0.9485 for $\mathrm{CO}$.

Fig. 8 shows the fluxes measured using the flux chamber method as a function of material age during two sampling events. The maximum fluxes observed were $121 \mathrm{~g} \mathrm{CO}_{2} \mathrm{~h}^{-1} \mathrm{~m}^{-2}$, $9.5 \mathrm{~g} \mathrm{CH}_{4} \mathrm{~h}^{-1} \mathrm{~m}^{-2}, 0.33 \mathrm{~g} \mathrm{~N}_{2} \mathrm{O} \mathrm{h}^{-1} \mathrm{~m}^{-2}$, and $0.13 \mathrm{~g} \mathrm{CO} \mathrm{h}^{-1} \mathrm{~m}^{-2}$. Fluxes were slightly lower at the beginning and end of composting. Measurements using the funnel showed similar fluxes (results not shown). Maximum fluxes were slightly higher than those reported by Beck-Friis et al. (2000) for composting of organic household waste $\left(5.0 \mathrm{~g} \mathrm{CH}_{4} \mathrm{~h}^{-1} \mathrm{~m}^{-2}\right.$ and $\left.0.06 \mathrm{~g} \mathrm{~N}_{2} \mathrm{O} \mathrm{h}^{-1} \mathrm{~m}^{-2}\right)$.

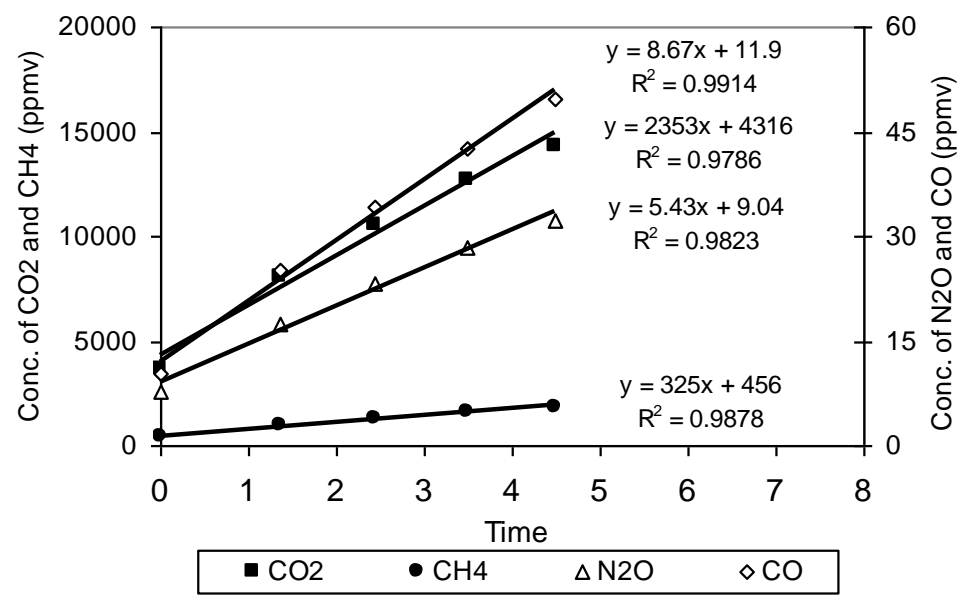

Fig. 7. Example of a flux measurement using the flux chamber method on material that is 114 days of age. The equation for linear regression fit and the $\mathrm{R}^{2}$ values are shown to the right of the time series. 


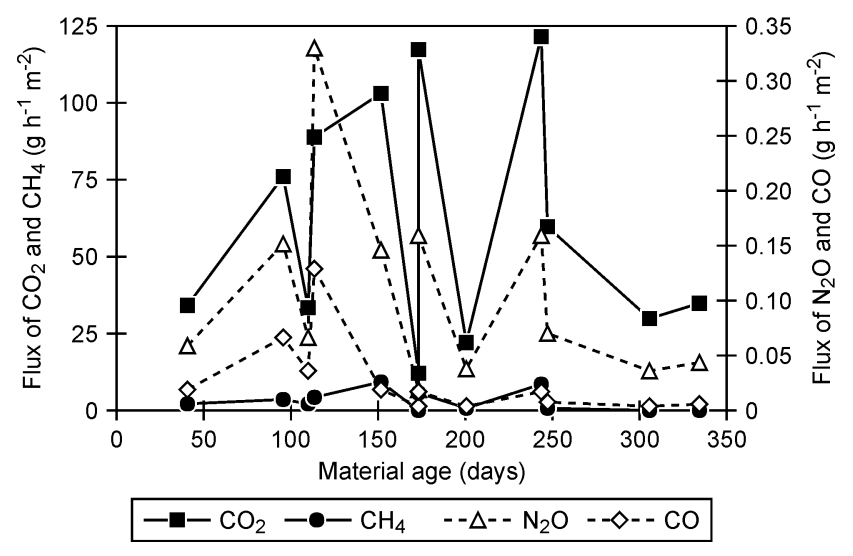

Fig. 8. Fluxes of $\mathrm{CO}_{2}, \mathrm{CH}_{4}$ (primary y-axis), $\mathrm{N}_{2} \mathrm{O}$, and $\mathrm{CO}$ (secondary y-axis) measured via flux chamber during composting of garden waste.

To provide a rough estimate of the annual GHG emissions from the facility, gas flux results from the flux chamber and the funnel measurements $\left(F_{\text {flux chamber }}\right.$ and $F_{\text {funnel; }}$ see [1] and [2]) were averaged over one year and scaled up for the whole site, by extrapolating the gas fluxes from the top area of the windrows to the whole length of all windrows (the entire area where the gases are assumed to escape). The estimated annual emissions using the flux chamber method were thus $107 \pm 30 \mathrm{Mg} \mathrm{CO}_{2}-\mathrm{C} \mathrm{yr}^{-1}, 16 \pm 6.1 \mathrm{Mg} \mathrm{CH}_{4}-\mathrm{C} \mathrm{yr}^{-1}, 0.44 \pm 0.03 \mathrm{Mg} \mathrm{N} \mathrm{O}_{2} \mathrm{~N}$

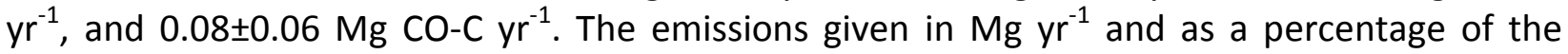
degraded element mass are presented in Table 3 and Table 4 together with the numbers for the three other methods used. In general, the results suggest that the small-scale methods (flux chamber and funnel) underestimated gaseous emissions. When relating the emissions to the $\mathrm{C}$ mass balance, it becomes evident that only $5.1 \pm 1.7 \%$ and $7.7 \pm 2.2 \%$ of degraded carbon was emitted as $\mathrm{CO}_{2}$ as determined with the funnel and static flux chamber, respectively. The smallscale methods could only account for $5.7 \% / 8.9 \%$ of the total $C$ losses.

The total emission measurements that were performed with the dynamic plume method showed significantly different results. Average emissions were $732 \pm 88 \mathrm{~kg} \mathrm{CO}_{2} \mathrm{~h}^{-1}(1748 \pm 210 \mathrm{Mg}$ $\left.\mathrm{CO}_{2}-\mathrm{C} \mathrm{yr}{ }^{-1}\right), 5.73 \pm 1.16 \mathrm{~kg} \mathrm{CH}_{4} \mathrm{~h}^{-1}\left(37.7 \pm 7.6 \mathrm{Mg} \mathrm{CH}_{4}-\mathrm{C} \mathrm{yr}^{-1}\right), 0.18 \pm 0.08 \mathrm{~kg} \mathrm{~N}_{2} \mathrm{O} \mathrm{h}^{-1}(0.99 \pm 0.46 \mathrm{Mg}$

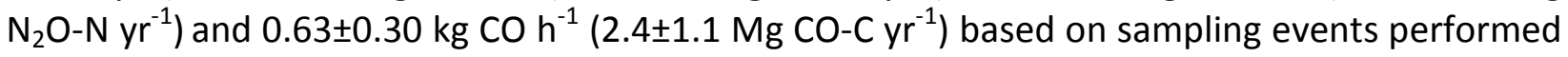
in October 2007 and April 2008. To estimate annual emissions, the emissions measured were assumed to be constant over the year and all the measurements (29 measurements during the two sampling events) have thus been averaged. On an element mass basis, the calculated loss of degraded $\mathrm{C}$ was $127 \pm 15 \%$ as $\mathrm{CO}_{2}, 2.7 \pm 0.6 \%$ as $\mathrm{CH}_{4}$, and $0.34 \pm 0.16 \%$ as $\mathrm{CO}$. In the case of $\mathrm{N}$, about $23 \pm 11 \%$ of the degraded $\mathrm{N}$ was emitted as $\mathrm{N}_{2} \mathrm{O}$. All the numbers for all methods are summarized in Table 4 and the total emission estimated for the dynamic plume method is presented in Table 5.

The mean concentrations and the predicted emissions (in $\mathrm{Mg} \mathrm{yr}^{-1}$ ) using the transport model are also given in Table 3. The model-predicted $\mathrm{N}_{2} \mathrm{O}$ and the $\mathrm{CO}$ emissions were within the same order of magnitude as the empirical data measured with the three field methods, whereas the $\mathrm{CH}_{4}$ emissions predicted by the model were significantly higher than measured in the field. The $381 \mathrm{Mg}$ of $\mathrm{CH}_{4}-\mathrm{C} \mathrm{yr}{ }^{-1}$ predicted by the model equates to $28 \%$ of the $\mathrm{C}$ degraded during composting. The calculation performed using the model did not include diffusion or methane 
oxidation. It is expected that inclusion of the former in the model would have increased the predicted $\mathrm{CH}_{4}$ emissions, while inclusion of the latter would have reduced predicted $\mathrm{CH}_{4}$ emissions.

Table 3. Mean concentration in compost pore space (in ppmv) and calculated/measured emissions (in $\mathrm{Mg} \mathrm{yr}^{-1}$ ) including standard deviations using the four different methods.

\begin{tabular}{|c|c|c|c|c|}
\hline & $\mathrm{CO}_{2}-\mathrm{C}$ & $\mathrm{CH}_{4}-\mathrm{C}$ & $\mathrm{N}_{2} \mathrm{O}-\mathrm{N}$ & $\mathrm{CO}-\mathrm{C}$ \\
\hline $\begin{array}{l}\text { Mean concentration in } \\
\text { compost pore space }(p p m v) \dagger\end{array}$ & 176900 & 67400 & 138 & 51 \\
\hline Flux chamber ( $\mathrm{Mg} \mathrm{yr}^{-1}$ ) & $107 \pm 30$ & $16 \pm 6.1$ & $0.44 \pm 0.03$ & $0.08 \pm 0.06$ \\
\hline Funnel $\left(\mathrm{Mg} \mathrm{yr}^{-1}\right)$ & $71 \pm 23$ & $7.6 \pm 0.54$ & $0.25 \pm 0.09$ & $0.07 \pm 0.03$ \\
\hline Dynamic plume $\left(\mathrm{Mg} \mathrm{yr}^{-1}\right)$ & $1748 \pm 210$ & $38 \pm 7.6$ & $1.0 \pm 0.46$ & $2.4 \pm 1.1$ \\
\hline Transport model $\left(\mathrm{Mg} \mathrm{yr}^{-1}\right) \boldsymbol{\dagger}$ & 999 & 381 & 1.8 & 0.29 \\
\hline
\end{tabular}

Table 4. Emission estimates (in \% of degraded element mass) from field campaigns performed between 2007 and 2008. The numbers are average numbers including standard deviations from two (flux chamber and dynamic plume) and three field campaigns (funnel) respectively.

\begin{tabular}{|c|c|c|c|c|}
\hline & \multicolumn{4}{|c|}{ Emission (\% of degraded element mass) } \\
\hline & $\mathrm{CO}_{2}-\mathrm{C}$ & $\mathrm{CH}_{4}-\mathrm{C}$ & $\mathrm{N}_{\mathbf{2}} \mathrm{O}-\mathrm{N}$ & $\mathrm{CO}-\mathrm{C}$ \\
\hline Flux chamber & $7.7 \pm 2.2$ & $1.2 \pm 0.4$ & $10 \pm 1.6$ & $0.006 \pm 0.005$ \\
\hline Funnel & $5.1 \pm 1.7$ & $0.6 \pm 0.04$ & $5.7 \pm 2.0$ & $0.005 \pm 0.004$ \\
\hline Dynamic plume & $127 \pm 15$ & $2.7 \pm 0.6$ & $23 \pm 11$ & $0.17 \pm 0.08$ \\
\hline Transport model + & 72 & 28 & 42 & 0.02 \\
\hline
\end{tabular}

Table 5. Emission estimates from treating $15540 \mathrm{Mg}$ of garden waste $\mathrm{yr}^{-1}$ at the composting facility in Århus using the dynamic plume method (October 2007 and April 2008).

\begin{tabular}{|l|c|c|c|c|}
\hline & $\begin{array}{c}\text { Emission } \\
\left(\mathbf{k g ~ M g}^{-1} \mathbf{~ w w )}\right)\end{array}$ & $\mathbf{G W P}_{\mathbf{1 0 0}}$ & $\begin{array}{c}\text { Emission } \\
\left.\text { (kg CO}_{\mathbf{2}} \text {-eq. } \mathbf{~ M g}^{-\mathbf{1}} \mathbf{~ w w )}\right)\end{array}$ & $\begin{array}{c}\text { Emission } \\
\text { (\% of degraded element mass) }\end{array}$ \\
\hline $\mathrm{CO}_{2}-\mathrm{C}$ & $113 \pm 14$ & 1 & $413 \pm 50$ & $127 \pm 15$ \\
\hline $\mathrm{CH}_{4}-\mathrm{C}$ & $2.4 \pm 0.5$ & 25 & $81 \pm 16$ & $2.7 \pm 0.6$ \\
\hline $\mathrm{N}_{2} \mathrm{O}-\mathrm{N}$ & $0.06 \pm 0.03$ & 298 & $30 \pm 14$ & $23 \pm 11$ \\
\hline $\mathrm{CO}-\mathrm{C}$ & $0.15 \pm 0.07$ & - & - & $0.17 \pm 0.08$ \\
\hline
\end{tabular}

\subsection{Gas emission dynamics}

The compost dynamics were investigated by measuring the flux of gases at the same monitoring points every three to four hours over a period of three days (funnel) and eight days (flux chamber). The variations in the fluxes over one of these monitoring points (representing material that is 150 days old) using the flux chamber are presented in Table 6 . The results show that the fluxes obtained in the chamber points varied significantly over the course of just a few hours, and by more than 4-fold over an eight day monitoring period (for the funnel this factor 
was between 9 and 10 for all gases). The standard deviations were fairly high for all gases measured, suggesting that the fluxes could be over- or underestimated compared to the average state depending on the time of measurement. The investigation did not account for seasonal nor meteorological variation, and it is therefore possible that the observed variations in gas emissions could be larger depending on the time of year. During the measurement period, the barometric pressure varied between 1001 and $1024 \mathrm{hPa}$, the wind speed between 1 and $5 \mathrm{~m} / \mathrm{s}$, and the only precipitation that was recorded was on day $2(1 \mathrm{~mm})$. The only trend observed was that the lowest fluxes were recorded during day 2 , where $1 \mathrm{~mm}$ of rain fell on the windrows.

Looking at the emission dynamics for the overall site as obtained with the dynamic plume method, it was found that over a three hour period the measured emission variability was in the range 9-25\% for $\mathrm{CO}_{2}$ and $\mathrm{CH}_{4}$ (expressed as one standard deviation among all plume transects divided by the average). For $\mathrm{CH}_{4}$, two emissions measurements were collected 15 hours apart in October 2007 and again in April 2008. The results of the two $\mathrm{CH}_{4}$ emission measurements for each sampling event differed by only 7-15\%.

Table 6. Fluxes of $\mathrm{CO}_{2}, \mathrm{CH}_{4}, \mathrm{~N}_{2} \mathrm{O}$, and $\mathrm{CO}$ during 8 days of composting at one location in the windrow system (representing approximately $\mathbf{1 5 0}$ days aged material). Measurements were performed using the flux chamber method.

\begin{tabular}{|c|c|c|c|c|}
\hline Time (days) & $\begin{array}{c}\mathrm{CO}_{2} \text { flux } \\
\left(\mathrm{g} \mathrm{h}^{-1} \mathrm{~m}^{-2}\right)\end{array}$ & $\begin{array}{c}\mathrm{CH}_{4} \text { flux } \\
\left(\mathrm{g} \mathrm{h}^{-1} \mathrm{~m}^{-2}\right)\end{array}$ & $\begin{array}{c}\mathrm{N}_{2} \mathrm{O} \text { flux } \\
\left(\mathrm{g} \mathrm{h}^{-1} \mathrm{~m}^{-2}\right)\end{array}$ & $\begin{array}{c}\text { CO flux } \\
\left(\mathrm{g} \mathrm{h}^{-1} \mathrm{~m}^{-2}\right)\end{array}$ \\
\hline 0.00 & 102 & 4.8 & 0.15 & 0.013 \\
\hline 0.01 & 103 & 4.0 & 0.14 & 0.013 \\
\hline 0.70 & 72 & 2.9 & 0.11 & 0.009 \\
\hline 0.72 & 45 & 1.6 & 0.06 & 0.007 \\
\hline 4.76 & 196 & 11.6 & 0.19 & 0.029 \\
\hline 4.91 & 79 & 2.1 & 0.13 & 0.011 \\
\hline 5.67 & 112 & 3.6 & 0.13 & 0.010 \\
\hline 5.93 & 96 & 3.7 & 0.13 & 0.016 \\
\hline 6.06 & 176 & 8.8 & 0.23 & 0.027 \\
\hline 6.67 & 199 & 10.9 & 0.26 & 0.028 \\
\hline 6.90 & 123 & 5.5 & 0.15 & 0.015 \\
\hline 7.00 & 115 & 5.4 & 0.14 & 0.016 \\
\hline 7.65 & 107 & 11.2 & 0.25 & 0.021 \\
\hline Mean flux & 117 & 5.8 & 0.16 & 0.017 \\
\hline Standard deviation & 47 & 3.5 & 0.06 & 0.008 \\
\hline $\begin{array}{l}\text { Max. factor between } \\
\text { highest and lowest flux }\end{array}$ & 4.5 & 7.0 & 4.2 & 4.4 \\
\hline
\end{tabular}

\section{Discussion}

Relatively high concentrations of $\mathrm{CH}_{4}$ were observed in the windrows at the Århus facility, particularly in the centre of the windrow where a maximum concentration of $44 \%$ was measured. These results indicate that fermentation was an ongoing process in some portions of 
the windrows. Beck-Friis et al. (2000) reported comparable $\mathrm{CH}_{4}$ concentrations (up to $47 \%$ ) in a study on composting of organic waste (2-2.5 m high windrows), while another study on green waste (3 $\mathrm{m}$ high windrows) reported a maximum concentration of $1.2 \%$ (Hellebrand, 1998). Beck-Friis et al. (2000) found the $\mathrm{CH}_{4}$ concentrations in compost gas are correlated to the size of the windrow (increasing emissions with increasing height), which could explain the high concentrations of $\mathrm{CH}_{4}$ in the compost gas at the Århus facility. In the study by Hellebrand (1998), it was reported that $\mathrm{N}_{2} \mathrm{O}$ was only produced under aerobic conditions whereas in the present study $\mathrm{N}_{2} \mathrm{O}$ concentrations were highest in the anaerobic zones (suggesting production from the establishment of denitrifying conditions in certain portions of the compost material). The high concentrations of GHGs in the pore space within the windrows indicates that compost windrows could serve as a significant source of GHGs emissions if these gases are not degraded (e.g., via microbial oxidation or reduction) prior to release to the atmosphere.

One of the traditional ways of determining gaseous emissions from landfills is to use static flux chambers (Scheutz et al., 2003, 2007). This method has been adapted for measuring compost gas emissions by Beck-Friis et al. (2000) and Sommer et al. (2004), but the method was not validated in either of those studies. A potential problem with the application of static flux chambers for this purpose is that the large spatial and temporal variations in emissions increase the difficulty in estimating whole-facility emissions, thereby necessitating the collection of numerous measurements.

The investigation of flux dynamics showed that the windrow system is highly dynamic and it is very difficult to accurately estimate windrow emissions using small-scale methods. The limitation of these methods could provide at least a partial explanation as to why GHG emissions in this study was underestimated; however, it cannot explain the whole discrepancy between the estimated emissions and the $C$ mass balance. Meteorological conditions are another factor that likely could have a significant effect on the results of GHG emission measurements at compost facilities. In this work, however, meteorological variations were minor and there was no observed correlation between meteorological changes and the flux measurements during the flux dynamics investigation. Nevertheless, changes in pressure, wind and precipitation have been shown to be very important when measuring emissions from landfills (Christophersen and Kjeldsen, 2001) and could also have some effect in compost systems. Another reason for the underestimation of gaseous fluxes by using the small-scale methods could be related to the design and performance of chambers. Hutchinson and Livingston (2001) suggest that all non-steady-state chambers should include a vent tube due to changes in pressure in the headspace during sampling. Livingston and Hutchinson (1995) state that when employing flux chambers in highly porous substrates underestimation is likely due to leakage of the enclosed air. This suggests that the chamber technique is less suitable for porous materials (which garden waste must be categorized as) and more suited for soil measurements. These points emphasize that one should be very careful when measuring GHG emissions with static chambers.

The small-scale methods were not found suitable for measuring gaseous emissions from composting of garden waste in windrow systems. Carbon losses measured with these methods were only $6-9 \%$ of the $C$ degraded, indicating these methods can yield results that significantly underestimate actual emissions. It is recognized that there could have been some $\mathrm{C}$ loss in leachate and/or in other $C$ containing gases (neither of which were quantified), but these losses 
are considered to have been minor and they have not been reported anywhere else in literature.

One solution could be to use the dynamic plume method for measuring the GHG emissions. It showed to fulfil the $C$ mass balance within an acceptable range, $127 \pm 15 \%$ of the degraded $C$ was lost as $C$, given an estimated overall absolute accuracy of about $18 \%$ for the method (Börjesson et al., 2009). The reason why the $\mathrm{CO}_{2}$ is overestimated could be due to the emission measurement method, errors on the chemical composition and thereby the $\mathrm{C}$ balance and time delay issues. The time delay issues could take place since the measured emission should be related directly to the mass of material that is present at the facility in that exact time period. In this study the gaseous emissions were related to the total mass in one year, because this number was the most exact available. The overestimated value could indicate that somewhat more waste material were present at the site at the two measuring campaigns than what estimated in the mass balance. The dynamic plume method has been used in other types of measurements at landfills and petrochemical plants, and is generally recognized as an effective method for quantifying gaseous emissions. As used in this work, however, the method did not account for seasonal variations because the measurements were collected over the course of just a few days. Nevertheless, the dynamic plume method was more accurate because it yield much better $\mathrm{C}$ mass balances than the small-scale methods. Emissions of $\mathrm{NH}_{3}$ or other $\mathrm{N}$ containing gases were not measured, so an accurate $\mathrm{N}$ balance could not be performed. Also, different soluble species of $\mathrm{N}$ could have been lost with the leachate (nitrate, nitrite and ammonium). The latter, however, was assumed to be of minor importance.

Simulations with a simple transport model (Hellebrand, 1998) predicted an unexpectedly high emission of $\mathrm{CH}_{4}$ (10 times greater than observed with dynamic plume measurements). The discrepancy between the model simulations and the dynamic plume measurements suggests that a number of assumptions in the model were not valid for the system in this study. Fig. 3 shows that the concentrations of gases are not evenly distributed in the windrows and the mean values that are calculated are thus very rough numbers. Also disproportional changes of concentration of the different gases were observed both in the compost pore space and in the flux of gases. Fig. 9 (top) shows the concentration of $\mathrm{CO}_{2}$ and $\mathrm{CH}_{4}$ in the compost pore space (from all measurements that were done at the site) plotted against each other. $\mathrm{The}^{\mathrm{CH}_{4}}$ concentration is very low when the $\mathrm{CO}_{2}$ concentration is below $20 \%$ but above $20 \% \mathrm{CO}_{2}$ the ratio is almost 1:1. The outer parts of the windrow (monitoring points $A 2, A 3, B 2, B 3$ and C3; represented by full line oval) are generally in the low end of the graph while the inner parts of the windrow (monitoring points $\mathrm{A} 1, \mathrm{~B} 1, \mathrm{C} 1$ and $\mathrm{C} 2$; represented by dotted line oval) are generally in the high end of the graph. The bottom graph in Fig. 9 shows the concentrations of $\mathrm{CO}_{2}$ and $\mathrm{CH}_{4}$ in the off-gases measured inside the flux chamber and the funnel (all measurements). This graph shows that the ratio between $\mathrm{CO}_{2}$ and $\mathrm{CH}_{4}$ is much higher in the offgases which could indicate that some of the $\mathrm{CH}_{4}$ is oxidized to $\mathrm{CO}_{2}$ on its way out of the windrow. This is not taken into consideration in the transport model and this could be the explanation for the large differences in $\mathrm{CH}_{4}$ emission estimates. There are clear indications of large changes in the proportions between the gases during composting. Thus the model cannot be used for all systems and especially not when high concentrations of $\mathrm{CH}_{4}$ are detected. 

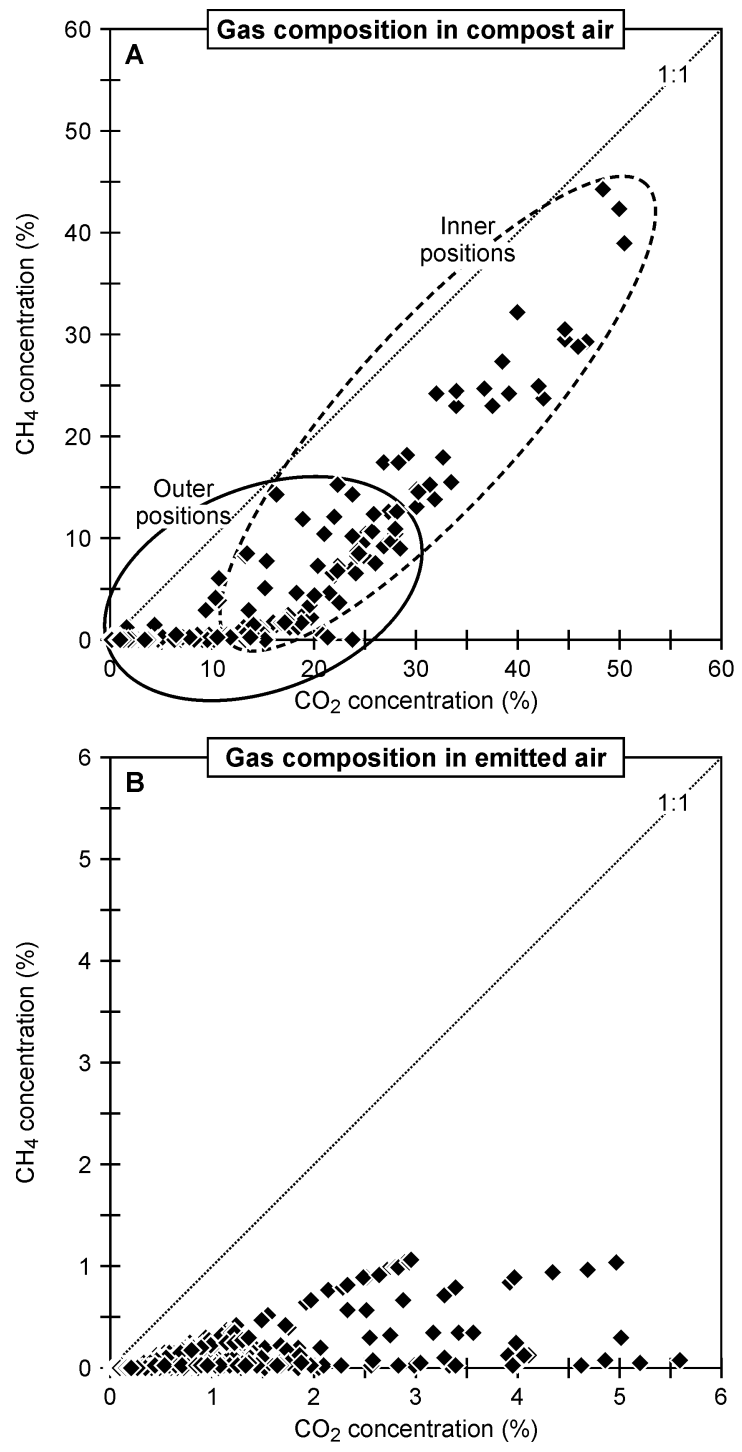

Fig. 9. A: Concentration of $\mathrm{CO}_{2}$ and $\mathrm{CH}_{4}$ in the compost pore space plotted against each other. The full line oval represents the outer parts of the windrow (monitoring points A2, A3, B2, B3, and T3) while the dotted line oval represents the inner parts (monitoring points $\mathrm{A1}$, B1, T1, and T2). B: Concentration of $\mathrm{CH}_{4}$ and $\mathrm{CO}_{2}$ in the emitted gases (inside the flux chamber/funnel) plotted against each other. The dotted line represents 1:1 relationship.

According to a guideline suggested by Amlinger et al. (2008), a GHG emission factor (considering only $\mathrm{CH}_{4}$ and $\mathrm{N}_{2} \mathrm{O}$ emissions) above 20-65 kg $\mathrm{CO}_{2}$-equivalents (eq.) $\mathrm{Mg}^{-1} \mathrm{ww}$ (biowaste or VFG waste) could indicate a system mismanagement. The GHG emission factor measured by Amlinger et al. (2008) was close to this interval (9-68 $\mathrm{kg} \mathrm{CO}_{2}$-eq. $\mathrm{Mg}^{-1} \mathrm{ww}$ ) which was the only apparent reason for this statement. In the present study the emission factor is $111 \pm 30 \mathrm{~kg} \mathrm{CO}$-eq. $\mathrm{t}^{-1} \mathrm{ww}$ (see Table 5), which could indicate that the management is not optimal. This could be due to the relatively high windrows and the low turning frequency. The total GHG emission could most likely be brought down with an optimized management of the compost facility. It is likely that smaller windrows and more frequent turning could facilitate lower production of $\mathrm{CH}_{4}$ and $\mathrm{N}_{2} \mathrm{O}$ during composting, which could lead to decreased emissions. 
The total contribution to global warming $\left(\mathrm{CH}_{4}\right.$ and $\left.\mathrm{N}_{2} \mathrm{O}\right)$ is $1720 \mathrm{Mg} \mathrm{CO}_{2}$-eq. $\mathrm{yr}^{-1}$, based on the $\mathrm{GWP}_{100}$ given by IPCC (Solomon et al., 2007). This however only includes the direct emissions from the process and not any GHG emissions related to the vehicle and machinery use during composting (from fossil $\mathrm{CO}_{2}$ ). The latter is however considered to be marginal (Boldrin et al., 2009a).

\section{Conclusion}

A comprehensive field investigation was performed at a garden waste composting facility in order to evaluate the composition and distribution of gases in compost windrow pore space and to quantify GHG emissions from the facility. The average concentrations of gases in the compost pore space were $8.8 \% \mathrm{O}_{2}, 17.7 \% \mathrm{CO}_{2}, 6.7 \% \mathrm{CH}_{4}, 138$ ppmv $\mathrm{N}_{2} \mathrm{O}$, and 51 ppmv $\mathrm{CO}$. The results of simulations using a simple transport model suggest that measurements of compost pore space gas alone are not sufficient to estimate GHG emissions from compost facilities to the atmosphere.

Two small-scale methods (flux chamber and funnel) investigated in this work were found to significantly underestimate the GHG emissions from the composting facility, as the C measured by these methods accounted for only $6-9 \%$ of the $C$ degraded. This result indicates that these methods did not effectively capture the total flux of gases emitted from the compost windrow system. In contrast, application of the dynamic plume method (total emission method) captured a significantly higher portion of GHGs, and found that $127 \pm 15 \%$ of the degraded $\mathrm{C}$ was lost as $\mathrm{CO}_{2}, 2.7 \pm 0.6 \%$ as $\mathrm{CH}_{4}$, and $0.34 \pm 0.16 \%$ as $\mathrm{CO}$. The measurements with the dynamic plume method generally agree with the overall $\mathrm{C}$ degradation during composting. Therefore, we conclude that use of a total emission method is required to accurately measure GHG emissions from full-scale composting facilities, which are too dynamic for small-scale methods. The total $\mathrm{CH}_{4}$ and $\mathrm{N}_{2} \mathrm{O}$ emissions were found to be $2.4 \pm 0.5 \mathrm{~kg} \mathrm{CH}_{4}-\mathrm{C} \mathrm{Mg}^{-1}$ ww and $0.06 \pm 0.03 \mathrm{~kg} \mathrm{~N}_{2} \mathrm{O}-\mathrm{N} \mathrm{Mg}^{-}$ ${ }^{1} \mathrm{ww}$ from a facility treating $15540 \mathrm{Mg}$ of garden waste $\mathrm{yr}^{-1}$ (2007), which adds up to $111 \pm 30 \mathrm{~kg}$ $\mathrm{CO}_{2}$-eq. $\mathrm{Mg}^{-1} \mathrm{ww}$.

This and other studies have found that compost windrow facilities may contribute significant concentrations of GHGs (specifically $\mathrm{CH}_{4}$ and $\mathrm{N}_{2} \mathrm{O}$ ) to the atmosphere. Therefore, compost facilities should be designed and operated so as to avoid the development of conditions that are prone to $\mathrm{CH}_{4}$ and $\mathrm{N}_{2} \mathrm{O}$ production. For example, windrow width should be minimized in order to provide easier access of air and thereby avoid the establishment of strongly anaerobic conditions in the waste. Similarly, compost material should be turned more frequently to facilitate aeration. Compost aeration seems to be one of the most important parameters for minimizing GHG emissions at compost facilities.

\section{Acknowledgements}

We would like to thank the staff at Affaldscenter Århus for their assistance and support during the solids and gas sampling. We also thank Per Haugsted Petersen and Lone Clowes of Rambøll in Odense, Denmark for kindly providing the equipment for the funnel method. The work was financed by the Municipality of Århus. 


\section{References}

Affaldscenter Århus. 2007. Grønt regnskab: Affaldscenter Århus, øvrige anlæg. Århus Kommune, $\begin{array}{lllll}\text { Natur } \quad \& \quad \text { Milj } \varnothing \quad \text { (In Available an } & \text { at }\end{array}$ http://aarhuskommune.dk/files/aak/aak/content/filer/magistratens_2._afdeling/aarhus_komm unale_vaerker/affaldvarme_aarhus/affald/groent_regnskab/groenne_regnskaber_2007/GRxNT _REGNSKAB_2007_-_xvrige_Anlxg.pdf. (verified 28 Apr. 2009).

Amlinger, F., S. Peyr, and C. Cuhls. 2008. Greenhouse gas emissions from composting and mechanical biological treatment. Waste. Manage. Res. 26:47-60.

Andersen, J.K., A. Boldrin, T.H. Christensen, and C. Scheutz. 2009. Mass balances and life cycle inventory for a garden waste windrow composting plant (Aarhus, Denmark). Waste. Manage. Res. (submitted).

Barth, J. 2008. Status of organic waste recycling in the EU, $2^{\text {nd }}$ Baltic Biowaste Conference: "Successful Implementation of Organic Waste Management in the Baltic States - Options and Tools for Municipalities", 29-30 ${ }^{\text {th }}$ of April 2008, the Ministry of Environment, Riga, Latvia.

Beck-Friis, B., M. Pell, U. Sonesson, H. Jönsson, and H. Kirchmann. 2000. Formation and emission of $\mathrm{N}_{2} \mathrm{O}$ and $\mathrm{CH}_{4}$ from compost heaps of organic household waste. Environmental Monitoring Assessment. 62:317-331.

Beck-Friis, B., S. Smårs, H. Jönsson, and H. Kirchmann. 2001. Gaseous emissions of carbon dioxide, ammonia, nitrous oxide from organic household waste in a compost reactor under different temperature regimes. J. Agric. Eng. Res. 78:423-430.

Boldrin, A., J.K. Andersen, J. Møller, E. Favoino, and T.H. Christensen. 2009a. Composting and compost utilization: Accounting of greenhouse gases and global warming contributions. Waste Manage. Res. 27, DOI: 0734242X09.

Boldrin, A., H. Spliid, and T.H. Christensen. 2009b. A novel approach for representative sampling of garden waste. Science of the Total Environment (submitted).

Börjesson, G., J. Samuelsson, J. Chanton, R. Adolfsson, B. Galle, and B.H. Svensson. 2009. A national landfill methane budget for Sweden based on field measurements, and an evaluation of IPCC models. Tellus. 61B:424-435.

Börjesson, G. and B.H. Svensson. 1997. Seasonal and diurnal methane emissions from a landfill and their regulation by methane oxidation. Waste Manage Res. 15:33-54.

Christensen, T.H., E. Gentil, A. Boldrin, A.W. Larsen, B.P. Weidema, and M. Hauschild. 2009. C balance, carbon dioxide emissions and global warming potentials in LCA-modeling of waste management systems. Waste Manage Res. 27, DOI: 10.1177/0734242X08096304. 
Christophersen, M. and P. Kjeldsen. 2001. Lateral gas transport in soil adjacent to an old landfill: factors governing gas migration. Waste Manage Res. 19:579-594.

ECN. 2008. Personal communication with Josef Barth, managing director, European Compost Network (ECN).

Galle, B., J. Samuelsson, B.H. Svensson, and J. Börjesson. 2001. Measurements of methane emissions from landfills using a time correlation tracer method based on FTIR absorption spectroscopy. Environ. Sci. Technol. 35:21-25.

Gy, P. 1998. Sampling for analytical purposes. John Wiley \& Sons Ltd., Chichester, UK.

He, Y., Y. Inamori, M. Mizuochi, H. Konk, N. Iwami, and T. Sun. 2001. Nitrous oxide emissions from aerated composting of organic waste. National Institute for Environmental Studies. Environ. Sci. Technol. 35:2347-2351.

Hellebrand, H.J. 1998. Emission of nitrous oxide and other trace gases during composting of grass and green waste. J. Agric. Eng. Res. 69:365-375.

Hellebrand, H.J., and W. Kalk. 2001. Emission of carbon monoxide during composting of dung and green waste. Nutr. Cycling Agroecosyst. 60:79-82.

Hellmann, B., L. Zelles, A. Palojärvi, and Q. Bai. 1997. Emission of climate-relevant trace gases and succession of microbial communities during open-windrow composting. Appl. Environ. Microbiol. 63:1011-1018.

Higson, S.P.J. 2003. Analytical chemistry. Oxford University Press Inc., New York.

Hutchinson, G.L., and Livingston, G.P. 2001. Vents and seals in non-steady-state chambers used for measuring gas exchange between soil and the atmosphere. European Journal of Soil Science. 52:675-682.

Livingston, G.P., and Hutchinson, G.L. 1995. Enclosed-based measurement of trace gas exchange: applications and sources of error. In: Biogenic trace gases: Measuring emissions from soil and water. Matson, P.A., and Harriss, R.C (eds.). Methods in ecology series. Blackwell Science Inc., Cambridge.

Mellqvist, J. 1999. Application of infrared and UV-visible remote sensing techniques for studying the stratosphere and for estimating anthropogenic emissions. Ph.D. dissertation, Chalmers University of Technology, Göteborg, Sweden, Paper 3:24.

Richter, F.M., R.A., Mendybaev, J.N. Christensen, I.D. Hutcheon, R.W. Williams, N.C. Sturchio, and D.B. Abelardo. 2006. Kinetic isotopic fractionation during diffusion of ionic species in water. Geochemica et Cosmochimica Acta. 70:277-289. 
Scheutz, C., J. Bogner, J. Chanton, D. Blake, and P. Kjeldsen. 2003. Comparative oxidation and net emissions of $\mathrm{CH}_{4}$ and selected non-methane organic compounds in landfill cover soils. Environ. Sci. Technol. 37:5150-5158.

Scheutz, C., J. Bogner, J.P. Chanton, D. Blake, M. Morcet, C. Aran, and P. Kjeldsen. 2007. Atmospheric emissions and attenuation of non-methane organic compounds in cover soils at a French landfill. Waste Manage. 28:1892-1908.

Solomon, S., D. Qin, M. Manning, R.B. Alley, T. Berntsen, N.L. Bindoff, Z. Chen, A. Chidthaisong, J.M. Gregory, G.C. Hegerl, M. Heimann, B. Hewitson, B.J. Hoskins, F. Joos, J. Jouzel, V. Kattsov, U. Lohmann, T. Matsuno, M. Molina, N. Nicholls, J. Overpeck, G. Raga, V. Ramaswamy, J. Ren, M. Rusticucci, R. Somerville, T.F. Stocker, P. Whetton, R.A. Wood, and D. Wratt. 2007. Technical summary. In: Climate change 2007: The physical science basis. Contribution of working group I to the fourth assessment report of the Intergovernmental Panel on Climate Change. [Solomon, S., D. Qin, M. Manning, Z. Chen, M. Marquis, K.B. Averyt, M. Tignor, and H.L. Miller (eds.)]. Cambridge University Press, Cambridge, United Kingdom and New York, NY, USA.

Sommer, S.G., S.M. McGinn, X. Hao, and F.J. Larney. 2004. Techniques for measuring gas emissions from a composting stockpile of cattle manure. Atmos. Environ. 38:4643-4652. 